Short Report

\title{
Adoptive Cell Therapy for Patients with Melanoma
}

\author{
Mark E. Dudley $\bowtie$ \\ Surgery Branch, National Cancer Institute, NIH, Bethesda, MD 20892-1201, USA
}

$\square$ Corresponding author: Mark Dudley, PhD. Surgery Branch, National Cancer Institute, NIH.

(c) Ivyspring International Publisher. This is an open-access article distributed under the terms of the Creative Commons License (http://creativecommons.org/ licenses/by-nc-nd/3.0/). Reproduction is permitted for personal, noncommercial use, provided that the article is in whole, unmodified, and properly cited.

Received: 2011.04.29; Accepted: 2011.06.03; Published: 2011.06.08

\begin{abstract}
Adoptive cell therapy can be an effective treatment for some patients with advanced cancer. This report summarizes clinical trial results from the Surgery Branch, NCI, investigating tumor infiltrating lymphocytes (TIL) and gene engineered peripheral blood $\mathrm{T}$ cells for the therapy of patients with melanoma and other solid tumors.
\end{abstract}

Key words: TIL, melanoma, NY-ESO-1, interleukin-2, lymphodepletion

Adoptive T cell therapy (ACT) consists of isolating tumor reactive lymphocytes from a patient, growing and activating them in the laboratory, and infusing them back into the autologous patient [1]. ACT can be an effective treatment for patients with refractory melanoma, and potentially other advanced cancers. Clinical trials in the Surgery Branch of the National Cancer Institute have focused on two aspects of ACT. First, the role of lymphodepletion is being studied, including its impact on persistence of the infused lymphocytes and improving clinical outcome. Second, the role of antigen specificity is being investigated by engineering lymphocytes to express new $\mathrm{T}$ cell receptors targeting them to tumors, increasing the pool of patients eligible for this therapy [2].

Several mechanisms have been identified in mouse models for how lymphodepletion improves antitumor efficacy in ACT [3]. These mechanisms include the elimination of cytokine "sinks" and accumulation of high levels of homeostatic cytokines like IL-7 and IL-15; elimination of CD4+CD25+ regulatory $\mathrm{T}$ cells that inhibit anti-tumor responses; activation of antigen presenting cells; and stimulation of lymphocytes by the transfer of hematopoietic progenitor cells. Which of these mechanisms are important for optimal cancer immunotherapy in human patients is not known. To investigate an optimal lymphodepleting regimen for ACT in patients, three sequential clinical trials were undertaken [4-6]. Patients were selected for these trials who had metastatic melanoma (many refractory to standard therapies) and who had a tumor-reactive, tumor infiltrating lymphocyte (TIL) culture available for treatment. After TIL transfer all patients received high dose interleukin(IL)-2 therapy consisting of 720,000 IU/kg three times per day to tolerance. An initial cohort of 43 patients received a non-myeloablative (NMA) lymphodepleting regimen consisting of two days of $60 \mathrm{mg} / \mathrm{kg}$ cyclophosphamide followed by $25 \mathrm{mg} / \mathrm{m}^{2}$ fludarabine. A second cohort of 25 patients received the same doses of NMA chemotherapy with the addition of 2Gy total body irradiation (TBI), and these patients also received CD34+ hematopoietic stem cells ( $>2$ million $/ \mathrm{kg}$ ) the day following TIL administration. A third cohort of 25 patients received the same doses of NMA chemotherapy with 12Gy TBI, and these patients also received CD34+ stem cells. The toxicities due to the lymphodepletion and high dose IL-2 were substantial but generally transient. One patient in the 2Gy cohort died from sepsis due to a pre-existing but unappreciated diverticular abscess. Five patients enrolled in the 12Gy TBI group developed elevated creatinine levels that stabilized or returned to normal without intervention. Toxicities due to TIL administration were rare and generally minor. Occasional patients had skin depigmentation or mild uveitis. 
The objective clinical response rates (RECIST) in the NMA, 2Gy, and $12 \mathrm{~Gy}$ cohorts were $49 \%, 52 \%$, and $72 \%$, and the complete response (CR) rates were $12 \%$, $20 \%$, and $40 \%$ [7]. Overall, 20 of the 93 patients treated with lymphodepletion plus TIL and IL-2 achieved a complete tumor regression. Nineteen of the 20 are ongoing with a minimum follow up time over three years. Regression of melanoma lesions was seen at all sites, including brain, and some responses were very rapid. The likelihood of response was not related to prior treatments or bulk of disease. The results from this remarkable group of patients are encouraging because few treatments for solid tumors result in durable complete responses, and the ability of ACT to mediate "cures" in these refractory metastatic melanoma patients suggests that this therapy should be investigated further.

Retrospective analysis revealed several correlates of treatment and response in this combined group of 93 patients. All patients exhibited elevated circulating levels of IL15 prior to TIL transfer, suggesting that the lymphodepletion may be acting through this mechanism to enhance anti-tumor function. T cell attributes associated with differentiation and proliferative potential, including CD27 expression and telomere length, also correlated with response. These observations motivated us to develop a simpler, more reliable methods of TIL production, termed "young" TIL[8]. Investigators at other institutions have also adopted simplified and reliable TIL production methods and have reported clinical responses in patients treated with this approach[9]. New research directions with TIL may include improved methods for TIL expansion, or combinations of ACT with ipilimumab, a BRAF inhibitor, IL-15, or another therapy.

ACT with TIL can be an effective therapy for some patients, but this approach is also logistically difficult and requires a surgical resection for each patient to access the endogenous $\mathrm{T}$ cell receptor (TCR) repertoire found in TIL. TCR gene engineering allows the production of tumor reactive lymphocytes for any patient from peripheral blood lymphocytes (PBL) [10]. The Surgery Branch has investigated several TCRs for retargeting PBL. A clinical trial recently reported by Robbins et al targeting the NY-ESO-1 antigen demonstrates some interesting features of this approach [11]. The NY-ESO-1 cancer/testes antigen is not expressed in normal adult tissues except the testes, which have no class I HLA expression so are not a T cell target. NY-ESO-1 is expressed by $10-50 \%$ of tumors of multiple histologies including melanoma, breast, prostate, thyroid, and ovarian. It is also expressed by about $80-90 \%$ of synovial cell sarcomas.
An NY-ESO-1 TCR that is HLA-A2 restricted was optimized for antigen binding, cloned into a retrovirus, and produced under GMP conditions for a clinical trial.

Eleven patients with refractory melanoma received peripheral blood lymphocytes (PBL) transduced to express the ESO TCR following NMA lymphodepletion with IL-2. Five patients had an objective response (RECIST) including two complete responses. Additionally, 6 patients with synovial cell sarcoma were treated with ESO TCR transduced PBL following NMA lymphodepletion with IL-2. Four patients responded to therapy. Toxicities due to the cells were minimal. These results demonstrate that solid tumors other than melanoma can respond to ACT when tumor reactive lymphocytes are administered in appropriately conditioned patients. Further clinical trials with NY-ESO-1 aimed at improving the response rate, extending the durability of responses, and increasing patient accrual to protocols are ongoing. Other antigens are expressed on tumors and susceptible to attack by retargeted lymphocytes including MAGE-A3 on tumors of multiple histologies, and CD19on lymphomas and leukemias.

These studies demonstrate that ACT can be a potent and effective therapy for patients with refractory melanoma. TIL therapy for melanoma can be widely applied, and studying the correlates of treatment and response allow us to improve next generation therapies. TCR gene engineering simplifies the manufacturing of the individual patient treatments and extends ACT to diverse tumor histologies.

\section{Conflict of Interest}

The author has declared that no conflict of interest exists.

\section{References}

1. Rosenberg SA, Restifo NP, Yang JC, Morgan RA, Dudley ME: Adoptive cell transfer: a clinical path to effective cancer immunotherapy. Nat Rev Cancer 2008; 8(4):299-308.

2. Brenner MK, Heslop HE: Adoptive T cell therapy of cancer. Curr Opin Immunol 2010; 22(2):251-257.

3. Wrzesinski C, Paulos CM, Kaiser A, Muranski P, Palmer DC, Gattinoni L, Yu Z, Rosenberg SA, Restifo NP: Increased intensity lymphodepletion enhances tumor treatment efficacy of adoptively transferred tumor-specific T cells. J Immunother 2010; 33(1):1-7.

4. Dudley ME, Wunderlich JR, Robbins PF, Yang JC, Hwu P, Schwartzentruber DJ, Topalian SL, Sherry R, Restifo NP, Hubicki AM, Robinson MR, Raffeld M, Duray P, Seipp CA, Rogers-Freezer L, Morton KE, Mavroukakis SA, White DE, Rosenberg SA: Cancer regression and autoimmunity in patients after clonal repopulation with antitumor lymphocytes. Science 2002; 298(5594):850-854.

5. Dudley ME, Wunderlich JR, Yang JC, Sherry RM, Topalian SL, Restifo NP, Royal RE, Kammula U, White DE, Mavroukakis SA, Rogers LJ, Gracia GJ, Jones SA, Man- 
giameli DP, Pelletier MM, Gea-Banacloche J, Robinson MR, Berman DM, Filie AC, Abati A, Rosenberg SA: Adoptive cell transfer therapy following non-myeloablative but lymphodepleting chemotherapy for the treatment of patients with refractory metastatic melanoma. J Clin Oncol 2005; 23(10):2346-2357.

6. Dudley ME, Yang JC, Sherry R, Hughes MS, Royal R, Kammula U, Robbins PF, Huang J, Citrin DE, Leitman SF, Wunderlich J, Restifo NP, Thomasian A, Downey SG, Smith FO, Klapper J, Morton K, Laurencot C, White DE, Rosenberg SA: Adoptive cell therapy for patients with metastatic melanoma: evaluation of intensive myeloablative chemoradiation preparative regimens. J Clin Oncol 2008; 26(32):5233-5239.

7. Rosenberg SA, Yang JC, Sherry RM, Kammula US, Hughes MS, Phan GQ, Citrin DE, Restifo NP, Robbins PF, Wunderlich JR, Morton KE, Laurencot CM, Steinberg SM, White DE, Dudley ME: Durable Complete Responses in Heavily Pretreted Patients with Metastatic Melanoma Using T Cell Transfer Immunotherapy. Clin Cancer Res 2011; epub.

8. Dudley ME, Gross CA, Langhan MM, Garcia MR, Sherry RM, Yang JC, Phan GQ, Kammula US, Hughes MS, Citrin DE, Restifo NP, Wunderlich J, Prieto PA, Hong JJ, Langan RC, Zlott DA, Morton KE, White DE, Laurencot C, Rosenberg SA: CD8+ enriched "young" tumor infiltrating lymphocytes can mediate regression of metastatic melanoma. Clin Cancer Res 2010; epub.

9. Besser MJ, Shapira-Frommer R, Treves AJ, Zippel D, Itzhaki O, Hershkovitz L, Levy D, Kubi A, Hovav E, Chermoshniuk N, Shalmon B, Hardan I, Catane R, Markel G, Apter S, Ben-Nun A, Kuchuk I, Shimoni A, Nagler A, Schachter J: Clinical Responses in a Phase II Study Using Adoptive Transfer of Short-term Cultured Tumor Infiltration Lymphocytes in Metastatic Melanoma Patients. Clin Cancer Res 2010; epub.

10. Morgan RA, Dudley ME, Rosenberg SA: Adoptive cell therapy: genetic modification to redirect effector cell specificity. Cancer J 2010; 16(4):336-341.

11. Robbins PF, Morgan RA, Feldman SA, Yang JC, Sherry RM, Dudley ME, Wunderlich JR, Nahvi AV, Helman LJ, Mackall CL, Kammula US, Hughes MS, Restifo NP, Raffeld M, Lee CC, Levy CL, Li YF, El-Gamil M, Schwarz SL, Laurencot C, Rosenberg SA: Tumor regression in patients with metastatic synovial cell sarcoma and melanoma using genetically engineered lymphocytes reactive with NY-ESO-1. J Clin Oncol 2011; 29(7):917-924. 